\title{
Thermophilic Anaerobic Digestion Modeling of Lignocellulosic Hot Water Extract using ADM1
}

\author{
Zahra Nikbakht Kenarsari Nirmal Ghimire Rune Bakke Wenche Hennie Bergland \\ Department of Process, Energy and Environmental Technology, University of South-Eastern Norway, \\ zahranikbakhtkenarsari@gmail.com, Nirmal.Ghimire@usn.no, Rune.Bakke@usn.no, \\ Wenche.Berglandeusn.no
}

\begin{abstract}
Lignocellulosic biomass is abundant and can become a major feed for anaerobic digestion methane production if its natural recalcitrance is overcome by pretreatment. Bio-degradable organic molecules were extracted by hot water (to produce "hydrolysate") from wood (Norway spruce). A high rate anaerobic sludge bed reactor fed the hydrolysate was modeled by the IWA Anaerobic Digestion Model No.1 (ADM1). Biodegradability kinetics for the hydrolysate material was obtained from batch tests at thermophilic condition, and the hydrolysis kinetic coefficient of carbohydrate $\left(k_{h y d}\right.$ ch $)$ found. Thus obtained $k_{\text {hyd_ch }}=0.44 \mathrm{~d}^{-1}$ was used to simulate UASB reactor performance at $55^{\circ} \mathrm{C}$ and comparing results to measured parameters from an experimental reactor at five different organic loading rates. The simulation results correlated well with the experimental results for biogas production rate, biogas composition and chemical oxygen demand. This shows that ADM1 is a powerful tool to predict the behavior of thermophilic anaerobic digestion (AD) of pretreated lignocellulosic feed using standard ADM1 parameters except for hydrolysis kinetics. Hydrolysis was identified as the overall rate limiting step in AD of such feed in UASB.
\end{abstract}

Keywords: thermophilic anaerobic digestion, OLR, lignocellulosic hydrolysate, hydrolysis kinetic, ADMI

List of symbols

$\begin{array}{ll}\text { Symbol } & \text { Description [Unit] } \\ \text { COD } & \text { Chemical Oxygen Demand [g COD] } \\ \text { CSTR } & \text { Continuous flow Stirred Tank Reactor } \\ \text { HRT } & \text { Hydraulic Retention Time [day] } \\ \text { HWE } & \text { Hot Water Extraction } \\ \text { OLR } & \text { Organic Loading Rate }[\mathrm{g} \mathrm{COD} / \mathrm{L} \cdot \text { day] } \\ \text { IN } & \text { Inorganic Nitrogen }\left[\mathrm{kmol} / \mathrm{m}^{3}\right] \\ k_{\text {hyd }} & \text { Hydrolysis kinetic coefficient } \\ k_{\text {dis }} & \text { Disintegration kinetic coefficient } \\ \text { S_ac } & \text { Soluble acetate }\left[\mathrm{kg} \text { COD } / \mathrm{m}^{3}\right] \\ \text { S_I } & \left.\text { Soluble inert [kg COD/m }{ }^{3}\right] \\ \text { S_su } & \text { Soluble Monosaccharides }\left[\mathrm{kg} \mathrm{COD} / \mathrm{m}^{3}\right] \\ \text { s_COD } & \text { Soluble Chemical Oxygen Demand }[\mathrm{g} \text { COD] } \\ \text { SRT } & \text { Solid Retention Time [day] } \\ \text { t_COD } & \text { Total Chemical Oxygen Demand }[\mathrm{g} \mathrm{COD]} \\ \text { UASB } & \text { Upflow Anaerobic Sludge Blanket } \\ \text { VFA } & \text { Volatile Fatty Acids } \\ \text { X_ch } & \text { Particulate carbohydrates }\left[\mathrm{kmol} / \mathrm{m}^{3}\right] \\ \text { X_I } & \text { Particulate inert }\left[\mathrm{kmol} / \mathrm{m}^{3}\right]\end{array}$

\section{Introduction}

Serious environmental pollution due to exhaustive use of fossil fuel has demanded an environment-friendly technology to convert woody biomass or its waste residue to biofuel. Woody biomass, especially Norway spruce, is found abundantly in Norway and requires efficient methods to break its recalcitrance for faster conversion. Biodegradation of lignocellulosic material is difficult because of the complex structures of lignin and other cell wall polysaccharides. As a result, anaerobic microorganisms are not able to easily use this lignocellulosic material and biogas production is hampered (David et al., 2018).Various pre-treatment methods have been tested to overcome this problem (Karuppiah and Azariah, 2019; Taherzadeh and Karimi, 2008). The main purpose of pre-treatment is to break the lignin which is the protective layer for cellulose and hemicellulose (Patinvoh et al., 2017). Also decreasing the crystallinity of cellulose and solubilizing the hemicellulose enhances the digestion (Karuppiah and Azariah, 2019). Hot Water Extraction (HWE) as a proposed pre-treatment process for lignocellulosic material cooks woody biomass in the water at high temperature and pressure (Amidon and Liu, 2009; Therasme et al., 2018) in order to produce liquid hydrolysate. The liquid product, after hot-water extraction, includes monosaccharides, polysaccharides, acetic acid, degraded lignin, and other low molecular weight extractable substances (Amidon and Liu, 2009).

Anaerobic digestion (AD) is a favorable technique due to its low environmental footprint (Kamali et al., 2016) and high energy recovery by methane production. Thermophilic $\mathrm{AD}\left(50-57^{\circ} \mathrm{C}\right)$ is known as a faster method compared to mesophilic $\mathrm{AD}\left(30-40^{\circ} \mathrm{C}\right)$ since the choice of temperature affects the growth of microorganism via influencing the kinetic parameters of the main anaerobic reactions. The temperature can play a key role regarding system stability, with poorer yield and process stability for thermophilic $\mathrm{AD}$, but better biogas and digestate quality have also been reported (Gebreeyessus and Jenicek, 2016). The higher temperature can also prevent $\mathrm{AD}$ culture contamination (Xia et al., 2013) but may have higher thermal energy requirement (Eddy et al., 2013). Therefore, it is 
interesting to test thermophilic $\mathrm{AD}$ of lignocellulosic hydrolysate.

Empirical methods based on pilot plant results are usually used to scale up thermophilic AD for various feed stocks. Mathematical modeling and simulation of $\mathrm{AD}$ can speed up such design work and provide the opportunity to test a wider range of $\mathrm{AD}$ process conditions at lower cost than piloting.

The Anaerobic Digestion Model No.1 (ADM1) (Batstone et al., 2002) has been applied for different AD systems and its performances studied for various substrates and reactor configurations (Gehring et al., 2013).

ADM1 is structured in several main steps including disintegration and hydrolysis, acidogenesis, acetogenesis and methanogenesis. The first order kinetics describe the extracellular solubilization processes such as disintegration and hydrolysis (1), while the intracellular biochemical reactions are described by Monod-type kinetics (Batstone et al., 2002b; Kaparaju et al., 2009).

$$
\rho=k_{h y d \_c h} \cdot X_{h y d \_c h}
$$

$\rho=$ hydrolysis rate of solid substrate (kg COD solid substrate $\mathrm{m}^{-3} \mathrm{~d}^{-1}$ where COD = chemical oxygen demand), $X_{\text {hyd_ch }}=$ solid carbohydrate concentration $(\mathrm{kg}$ COD solid substrate $\mathrm{m}^{-3}$ ), $\mathrm{k}_{\text {hyd_ch }}=$ temperature dependent kinetic parameter for hydrolysis $\left(\mathrm{d}^{-1}\right)$.

Recommended relevant model parameters for most ADM1 reactions are published (Batstone et al., 2002a) but not key kinetic parameters for thermophilic high rate hydrolysate digestion. Therefore, the aim of this study was to determine kinetic parameters for thermophilic AD of thermally hydrolyzed Norwegian spruce. This involved parameter estimation based on batch experiments and model evaluation based on continuous flow tests with increasing organic loading rates of this new substrate.

\section{Materials and Methods}

$\mathrm{AD}$ of hydrolysate from hot water extraction of lignocellulosic Norwegian spruce (Picea abies) is tested in batch and continuously fed UASB lab scale reactors with increasing load and modeled by ADM1.

\subsection{Material Characterization}

\subsubsection{Substrate}

Hydrolysate from 300 minutes hot water extraction at $140^{\circ} \mathrm{C}$ was used as substrates for both batch and continuously fed UASB reactors. Macronutrients (Table 1) and micronutrients (Table 2) were added in to provide required nutrients, COD:N:P ratio of 350:5:1 (Baeta et al.,2013). Initial $\mathrm{pH}$ was adjusted by $\mathrm{NaOH}$ to around 7 . Substrate organics and ammonium are given in Table 3.
Table 1: Composition and concentration of macronutrients in substrate.

\begin{tabular}{|l|l|}
\hline \multicolumn{2}{|c|}{ Macronutrients } \\
\hline Type of chemical & Concentration $\left(\boldsymbol{m g} \boldsymbol{L}^{-\boldsymbol{I}}\right)$ \\
\hline $\mathrm{NH}_{4} \mathrm{Cl}$ & 1245.4 \\
\hline$\left(\mathrm{NH}_{4}\right) \mathrm{H}_{2} \mathrm{PO}_{4}$ & 148.4 \\
\hline$\left(\mathrm{NH}_{4}\right)_{2} \mathrm{HPO}_{4}$ & 49.8 \\
\hline $\mathrm{MgCl}_{2} \cdot 6 \mathrm{H}_{2} \mathrm{O}$ & 599.2 \\
\hline $\mathrm{CaCl}_{2} \cdot 2 \mathrm{H}_{2} \mathrm{O}$ & 211.7 \\
\hline $\mathrm{NaHCO}_{3}$ & 2800 \\
\hline
\end{tabular}

Table 2: Composition and concentration of micronutrients in substrate.

\begin{tabular}{|l|l|}
\hline \multicolumn{2}{|c|}{ Micronutrients } \\
\hline \multicolumn{1}{|c|}{ Type of chemical } & \multicolumn{1}{c|}{$\begin{array}{c}\text { Concentration } \\
\left(\text { mg L }^{-1}\right)\end{array}$} \\
\hline Yeast Extract & 10 \\
\hline $\mathrm{FeCl}_{3} \cdot 6 \mathrm{H}_{2} \mathrm{O}$ & 0.8 \\
\hline $\mathrm{ZnCl}_{2}$ & 20.8 \\
\hline $\mathrm{MnCl}_{2} \cdot 4 \mathrm{H}_{2} \mathrm{O}$ & 0.19 \\
\hline$\left(\mathrm{NH}_{4}\right)_{6} \mathrm{Mo}_{7} \mathrm{O}_{24} \cdot 4 \mathrm{H}_{2} \mathrm{O}$ & 0.26 \\
\hline $\mathrm{AlKO}_{8} \mathrm{~S}_{2} \cdot 12 \mathrm{H}_{2} \mathrm{O}$ & 0.04 \\
\hline $\mathrm{CoCl}_{2} \cdot 6 \mathrm{H}_{2} \mathrm{O}$ & 0.8 \\
\hline $\mathrm{NiCl}_{2} \cdot 6 \mathrm{H}_{2} \mathrm{O}$ & 2.08 \\
\hline $\mathrm{H}_{3} \mathrm{BO}_{3}$ & 0.48 \\
\hline $\mathrm{CuCl}_{2} \cdot 2 \mathrm{H}_{2} \mathrm{O}$ & 1.28 \\
\hline $\mathrm{HCl}$ & 80 \\
\hline
\end{tabular}

Table 3: Substrate organics and ammonium.

\begin{tabular}{|l|l|}
\hline Parameter & $\begin{array}{l}\text { Measured } \\
\text { value }\left(\mathrm{g}^{-1}\right)\end{array}$ \\
\hline $\mathrm{t}$-COD & $22 \pm 2$ \\
\hline $\mathrm{s}-\mathrm{COD}$ & $20 \pm 2$ \\
\hline$N H_{4}^{+}$ & $0.30 \pm 0.02$ \\
\hline Acetate & $0.59 \pm 0.09$ \\
\hline VFA & $0.59 \pm 0.09$ \\
\hline Arabinose & $1.63 \pm 0.02$ \\
\hline Galactose & $1.67 \pm 0.05$ \\
\hline Glucose & $1.55 \pm 0.05$ \\
\hline Xylose & $1.95 \pm 0.04$ \\
\hline Mannose & $5.1 \pm 0.1$ \\
\hline Total sugars & $11.9 \pm 0.3$ \\
\hline
\end{tabular}

\subsubsection{Inoculum}

Granular sludge inoculum (Table 4) used was from a mesophilic industrial internal recirculation reactor treating paper mill effluent. The sludge was adapted for thermophilic condition for $53 \mathrm{~d}$ before being used in the batch test and $20 \mathrm{~d}$ adaptation till stable operation in the UASB test. 
Table 4: Properties of granular sludge.

\begin{tabular}{|l|l|}
\hline Parameters & Values \\
\hline Density $\left(\mathrm{kg} \mathrm{m}^{-3}\right)$ & $1.00-1.09$ \\
\hline Diameter $(\mathrm{mm})$ & $0.6-2.7$ \\
\hline Settling velocity $\left(\mathrm{m} \mathrm{h}^{-1}\right)$ & $68-71$ \\
\hline Total Solids $\left(\mathrm{g} \mathrm{L}^{-1}\right)$ & 181.0 \\
\hline Volatile Solids $\left(\mathrm{g} \mathrm{L}^{-1}\right)$ & 119.4 \\
\hline $\mathrm{pH}$ & 7.46 \\
\hline
\end{tabular}

\subsection{Batch Reactors Set up}

$100 \mathrm{~mL}$ syringes were used as batch reactors in accordance with (Østgaard et al., 2017) with $15 \mathrm{~mL}$ inoculum. They were fed 4, 6.7, 13.4 and $20 \mathrm{~mL}$ of hydrolysates (Table 3 ) with three parallels for each COD loadings including control blank reactors to correct for biogas generated from the inoculum, all operated for 38 d at $55^{\circ} \mathrm{C}$.

\subsection{UASB Reactors Set up and Operation}

Two parallel glass vessel reactors (Bergland et al., 2015) with $345 \mathrm{~mL}$ liquid volume were used as UASB reactors. Half the reactor volumes were filled with granular sludge (Table 4). The substrate was kept cool $\left(4{ }^{\circ} \mathrm{C}\right)$. Culture adaptation started at $35^{\circ} \mathrm{C}$ and organic loading rate, $\mathrm{OLR}=0.65\left[\mathrm{gCOD} \mathrm{L}^{-1} \mathrm{~d}^{-1}\right]$ followed by $2^{\circ} \mathrm{C}$ daily increases to $55^{\circ} \mathrm{C}$. Then, followed the $52 \mathrm{~d}$ test period with step load increases (Table 5).

Table 5: The UASB operation conditions as hydraulic (HRT) and organic (OLR) loading rates.

\begin{tabular}{|c|c|c|}
\hline Time interval & $\begin{array}{c}H R T \\
{[d]}\end{array}$ & $\begin{array}{c}O L R \\
{[g C O D} \\
{\left[\begin{array}{l}\text { I-1 } \\
\left.L^{-1}\right]\end{array}\right.}\end{array}$ \\
\hline From d 1 to $d 16$ & 34.5 & 0.65 \\
\hline From d 17 to d 27 & 17.25 & 1.29 \\
\hline From d 28 to d 37 & 11.5 & 1.94 \\
\hline From d 38 to d 48 & 8.62 & 2.59 \\
\hline From d 49 to d 53 & 5.75 & 3.88 \\
\hline
\end{tabular}

\subsection{Analytical Methods}

UASB biogas production was monitored continuously and gas composition measured twice a week by gas chromatography (SRI 8610-C) as described in (Bergland et al., 2015). Liquid phase COD (total and soluble), volatile fatty acids (VFAs), including acetate, propionate, butyrate, iso-butyrate, valerate, iso-valerate, iso-caprionate, caprionate and heptanoic acid, $\mathrm{pH}$ and ammonium content $\left(\mathrm{NH}_{4}^{+}\right)$were sampled and measured as described in (Bergland et al., 2015). Batch reactor biogas production was measured manually in accordance with $\emptyset$ stgaard et al. (2017).

\subsection{Modelling and Simulation Methods}

The Anaerobic Digestion Model No. 1 (ADM1) was applied to model the processes with stoichiometric coefficients, equilibrium coefficients and dynamic states and algebraic variables as proposed by (Batstone et al., 2002b), for all biochemical and physio-chemical processes, with the following exception: lignocellulosic hydrolysate as feed is introduced here. The only model modification assumed necessary is the hydrolysis of this new substrate and, considering the characteristics of the substrate and inoculum (Table 3 and 4), input values for simulation (Table 6) are based on some assumptions:

- 10 percent of the total feed COD is inert (based on batch tests).

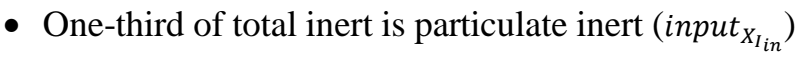
and two-thirds is soluble inert (input ${ }_{S_{I_{\text {in }}}}$ ).

- The feed amount of biodegradable particulate carbohydrates (input $_{X_{C_{\text {in }}}}$ ) used is assumed to be total particulates minus the inert fraction (2).

- The input of biodegradable soluble sugars input $\left._{S_{s u_{i n}}}\right)$ used as all soluble organics $\left(s_{C O D}\right)$ minus soluble inert and acids (dominated by acetic acid so used measured ( input $\left._{S_{a c_{i n}}}\right)(3)$.

$$
\begin{aligned}
& \text { input }_{X_{C h_{\text {in }}}}=(\text { total particulate })-\left(\text { input }_{X_{I_{\text {in }}}}\right) \\
& \text { input }_{S_{S u_{i n}}}=\left(s_{-} C O D\right)-\left(\text { input }_{S_{I_{\text {In }}}}\right)-\left(\text { input }_{S_{a c_{i n}}}\right)
\end{aligned}
$$

Table 6: Parameters used for simulation in the ADM1

\begin{tabular}{|c|c|c|c|}
\hline $\begin{array}{c}\text { Type of } \\
\text { parameter }\end{array}$ & $\begin{array}{l}\text { Formula for } \\
\text { calculation }\end{array}$ & Amount & Unit \\
\hline t_COD & & 22.31 & $\mathrm{kgCOD} \mathrm{^{-3 }}$ \\
\hline s_COD & & 20.04 & $\mathrm{kgCOD} \mathrm{\textrm {m } ^ { - 3 }}$ \\
\hline $\begin{array}{l}\text { Total } \\
\text { particulate }\end{array}$ & $\begin{array}{l}=\left(\mathrm{t} \_\mathrm{COD}-\right. \\
\text { s_COD })\end{array}$ & 2.27 & $\mathrm{kgCOD} \mathrm{m}^{-3}$ \\
\hline $\begin{array}{l}\text { Inert }(10 \% \mathrm{t}- \\
\text { COD) }\end{array}$ & $=\left(0.1 * \mathrm{t} \_\mathrm{COD}\right)$ & 2.23 & $\mathrm{kgCOD} \mathrm{m}^{-3}$ \\
\hline Input_X_I_in & $=(1 / 3 *$ inert $)$ & 0.74 & $\mathrm{kgCOD} \mathrm{m}^{-3}$ \\
\hline Input_S_I_in & $=(2 / 3 *$ inert $)$ & 1.49 & $\mathrm{kgCOD} \mathrm{\textrm {m } ^ { - 3 }}$ \\
\hline Input_X_C_in & & 0.00 & $\mathrm{kgCOD} \mathrm{m}^{-3}$ \\
\hline $\begin{array}{l}\text { Input_X_Ch_i } \\
\mathrm{n}\end{array}$ & $\begin{array}{l}=[(\text { total particulate }) \\
\text { - (input_X_I_in) }]\end{array}$ & 1.53 & $\mathrm{kgCOD} \mathrm{m}^{-3}$ \\
\hline Input_S_ac_in & & 0.63 & $\mathrm{kgCOD} \mathrm{m}^{-3}$ \\
\hline Input_S_su_in & $\begin{array}{l}=\left[\left(\mathrm{s} \_C O D\right) \text { - }\right. \\
\text { (input_S_I_in) - } \\
\text { (input_S_ac_in)] }\end{array}$ & 17.92 & $\mathrm{kgCOD} \mathrm{m}^{-3}$ \\
\hline Input_S_IN_in & & 0.016 & $\mathrm{~mol} \mathrm{~L}^{-1}$ \\
\hline Volume & & 0.00035 & $\mathrm{~m}^{3}$ \\
\hline Temperature & & 328 & $\mathrm{~K}$ \\
\hline
\end{tabular}
model 
- The feed ammonium concentration, "Input_S_IN_in" is set to $0.016 \mathrm{~mol} \mathrm{~L}^{-1}$ based on the adde nutrients (Tables 1 and 2).

- Disintegration and hydrolyze kinetic parameters for thermophilic high rate was not specified by (Batstone et al., 2002b). The values for mesophilic high rate (Table 7) are therefore used for the hydrolysis of protein and lipids while the hydrolysis kinetic factor of carbohydrate $\mathrm{k}_{\text {hyd_ch }}$ was assumed representative for the substrate and obtained from the batch test using equation 4. Disintegration high rate is assumed the same as disintegration solid.

$B=B_{0}\left(1-e^{-k t}\right)$

$\mathrm{B}_{0}$ is the total biogas production and $\mathrm{B}$ is the biogas production at the given time $\mathrm{t}$ and $\mathrm{k}=\mathrm{k}_{\mathrm{hyd}}$ ch.

Table 7: Kinetic parameters used for disintegration and hydrolysis as recommended by (Batstone et al., 2002b) and as used for the unique conditions tested here.

\begin{tabular}{|c|c|c|c|c|}
\hline \multirow[t]{2}{*}{ Parameter } & \multicolumn{3}{|c|}{$\begin{array}{l}\text { Proposed by (Batstone et al. } \\
\qquad 2002 b)\end{array}$} & \multirow{2}{*}{$\begin{array}{l}\begin{array}{l}\text { Used in } \\
\text { this } \\
\text { project }\end{array} \\
\text { Thermo- } \\
\text { philic high- } \\
\text { rate }\left(55^{\circ} \mathrm{C}\right)\end{array}$} \\
\hline & $\begin{array}{l}\text { Meso- } \\
\text { philic } \\
\text { high-rate } \\
\left(35^{\circ} \mathrm{C}\right)\end{array}$ & $\begin{array}{l}\text { Mesophilic } \\
\text { solids } \\
\left(35^{\circ} \mathrm{C}\right)\end{array}$ & $\begin{array}{l}\text { Thermo- } \\
\text { philic } \\
\text { solids } \\
\left(55^{\circ} \mathrm{C}\right)\end{array}$ & \\
\hline$k_{d i s}\left(d^{-1}\right)$ & 0.4 & 0.5 & 1.0 & 1.0 \\
\hline$k_{h y d_{-} c h}\left(d^{-1}\right)$ & 0.25 & 10 & 10 & 0.44 \\
\hline$k_{h y d \_p r}\left(d^{-1}\right)$ & 0.2 & 10 & 10 & 0.2 \\
\hline$k_{\text {hyd_li }}\left(d^{-1}\right)$ & 0.1 & 10 & 10 & 0.1 \\
\hline
\end{tabular}

High rate reactors (e.g. UASB) are characterized by long solids retention time compared to hydraulic retention time (SRT $>$ HRT), modeled by a t_res_x (difference between sludge and hydraulic retention time) factor. Its value is however unknown, so it was assessed by simulating different t_res_x values.

\section{Results and Discussion}

The $k_{\text {hyd_ch }}$ parameter is first estimated by the batch experiment and then the model evaluated by comparison to the UASB test.

\subsection{Hydrolysis Kinetic Coefficient}

Hydrolysis kinetic coefficient $\left(k_{\text {hyd_ch }}\right)$ for the carbohydrate was calculated based on Eq. 4 and batch data (Figure 1) to be $0.44 \mathrm{~d}^{-1}$ with low standard deviations between the parallels.

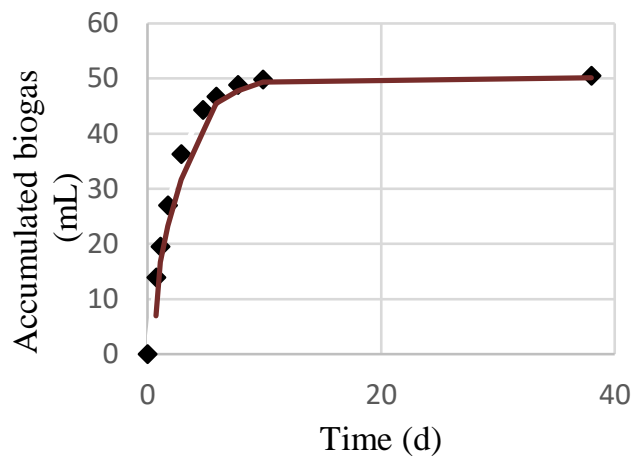

Figure 1. Batch test data and fitted line to calculate $k_{\text {hyd_ch }}$

\subsection{Sludge Retention Time}

The t_res_x value (difference between sludge and hydraulic retention time in the UASB) cannot be measured so it was assessed by simulations using different t_res_x values equal to 5, 15, 25 and $40 \mathrm{~d}$. The experimental and simulated results correlated quite well for all measured parameters for t_res_x $=40 \mathrm{~d}$, as seen for COD in Figure 2. Total COD was lower than simulated while simulated soluble COD was close to measured value after the first $17 \mathrm{~d}$ with the lowest load. t_res_x > $40 \mathrm{~d}$ was also tested (not shown) but without significant effects on concentrations so t_res_x $=40 \mathrm{~d}$ was used for the following simulations.
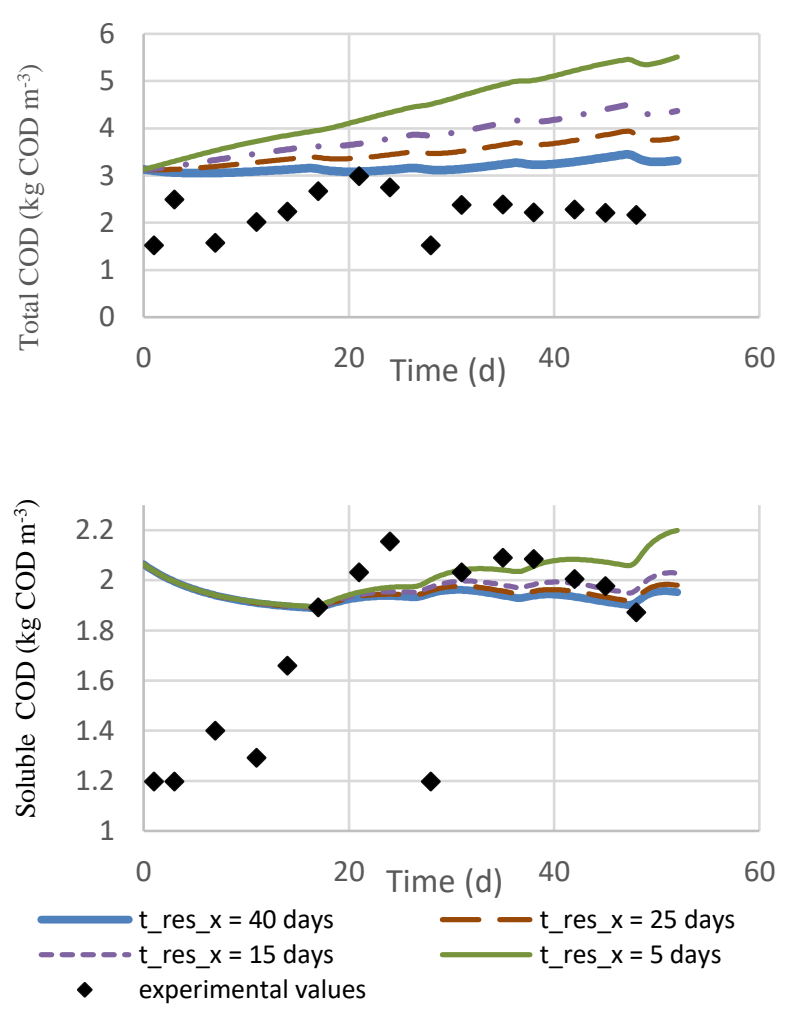

Figure 2. Total and soluble UASB effluent COD values. 


\subsection{Biogas Production}

The measured and simulated biogas production rate (Figure 3) deviated initially until day 12, perhaps due to incomplete adaptation to thermophilic conditions. Thereafter the biogas production was close to the simulated values for the lowest OLRs indicating adapted culture. The model predicted somewhat higher yields than measured at the higher ORLs. The increases in biogas production following each step increase in OLR were predicted well but not the subsequent drops in production. These deviations show that some adaptation to higher loads are needed and that such is not accounted for in ADM1.

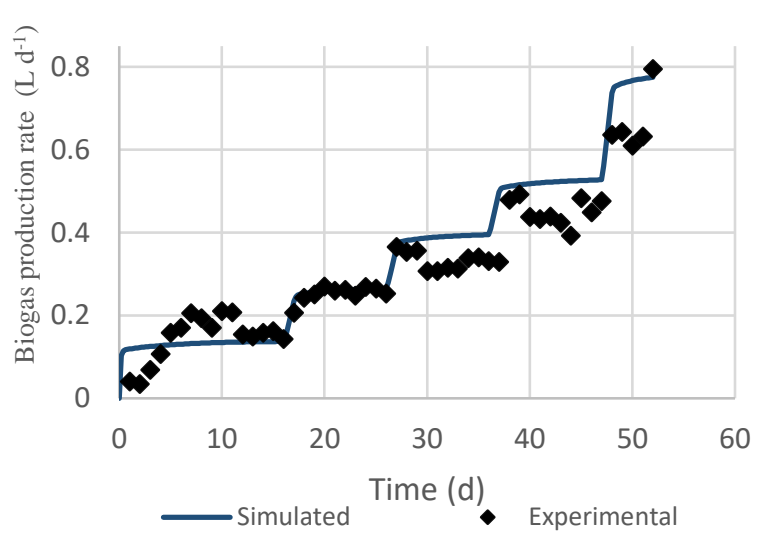

Figure 3. Simulated and experimental values for UASB biogas production rate $\left(\mathrm{L} \mathrm{d}^{-1}\right)$.

The model was also used to simulate much higher loads than tested (not shown) by continuing the step increases used in the test and it predicts that much higher loads than tested can be applied while maintaining stable operation and biogas yield. This is important for the economy of such fuel production plants since capital cost depends on reactor size. This exercise also demonstrates how the model can be used to evaluate conditions that would be very time-consuming and costly to test experimentally.

\subsection{Limiting Step}

The increase in OLRs showed no VFAs accumulation during the experiments while the model predicts temporary VFA accumulations after each step increases (Figure 4). Both measured and simulated values are, however, low and far enough the tolerable level for smooth reactor performance: $<2 \%$ of acetic, butyric and propionic acid concentrations of 2.4, 1.8 and 0.9 $\left(\mathrm{kg} \mathrm{m}^{-3}\right)$, respectively, reported to be of threshold value (Kim et al., 2002). This implies that the reactors had stable conditions with no signs of limitations of the methanogenesis at the tested loads.

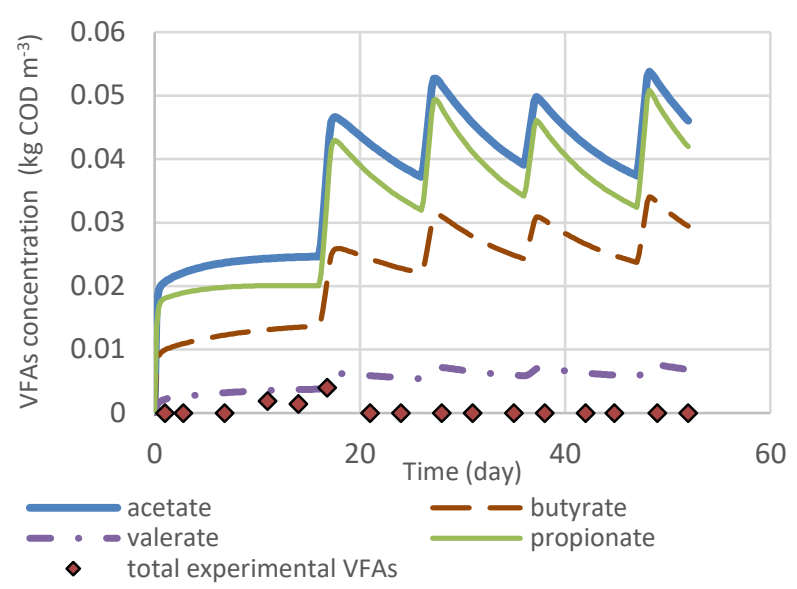

Figure 4. VFAs concentration experimental and simulated values for 52 days by increasing organic loading rate (OLR).

This is also seen by the stable methane content in the biogas, simulated and measured (Figure 5). These results also confirm that it was a correct modeling assumption to only adapt hydrolysis of ADM1 to the given conditions while the latter stages (methanogenesis etc.) were kept according to (Batstone et al., 2002), since these were not limiting steps for the overall process performance. This implies that hydrolysis is the rate limiting step of lignocellulosic hydrolysate $\mathrm{AD}$ in UASB. This seems reasonable given that $90 \%$ of feed organics is soluble (Table 3 ).

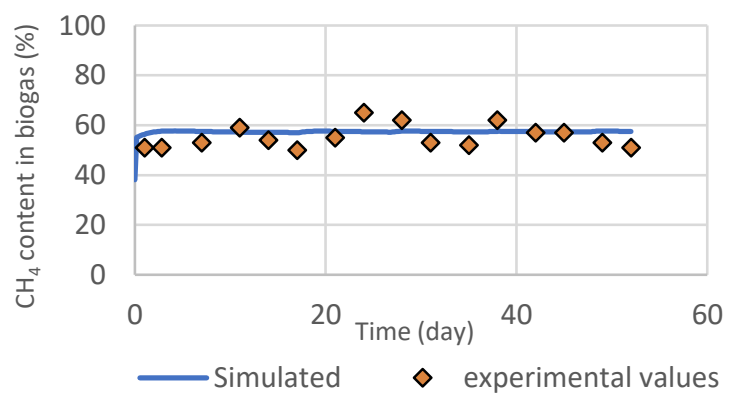

Figure 5. Simulated and experimental UASB biogas methane content.

\subsection{Biomass}

The active biomass cannot be accurately measured by existing methods so mass development of the main groups of microorganism in $\mathrm{AD}$ is studied by simulations (Figure 6). The figure shows that sugar consuming bacteria will be most abundant on such feed. The time allowed for each OLR tested, except the first, was too short to reach true steady state (even if biogas production stabilized) since biomass was still increasing for all seven microbial groups at the end of each OLR test. This supports the above suggestion that some deviations between simulated and measured value can be due to too short time for the slow growing $\mathrm{AD}$ 
microorganism to adapt to the higher loads. AD cultures have been reported to require months to adapt to new conditions (Nordgård et al., 2017).

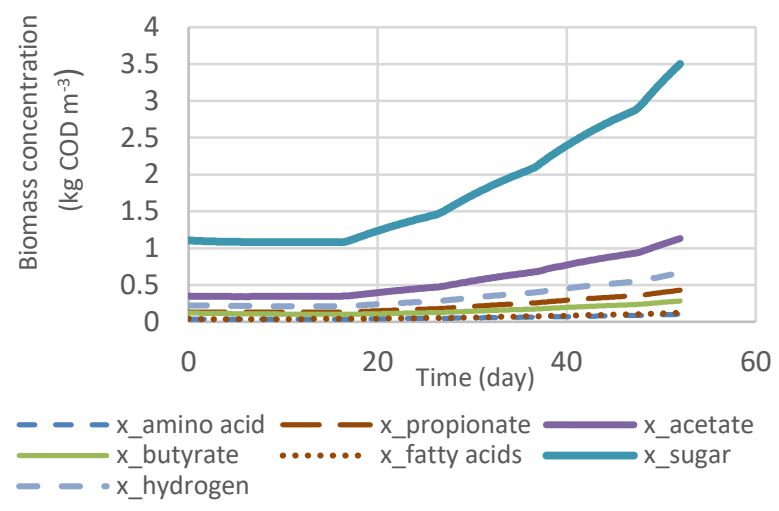

Figure 6. Simulated UASB biomass concentration development for the seven microbial groups in ADM1 during the $52 \mathrm{~d}$ test with increasing OLR.

\subsection{Inhibition}

The simulated inhibition (Figure 7) was low with slight hydrogen concentration inhibition of the propionate degradation (reducing the rate to around $80 \%$ of maximum) and butyrate degradation (reduced to $90 \%$ ). The $\mathrm{NH}_{3}$ concentration reduced the acetate degradation rate to $90 \%$ of not inhibited rate. There may however occur inhibition not accounted for due to unknown inhibitors in the feed. Lignocellulosic hydrolysate may contain furfural and HMF (5-hydroxymethylfurfural) that can inhibit microorganisms. This should be further studied and included in the model if relevant. If so, it could narrow the gaps between simulated and measured methane production (Figure 3).

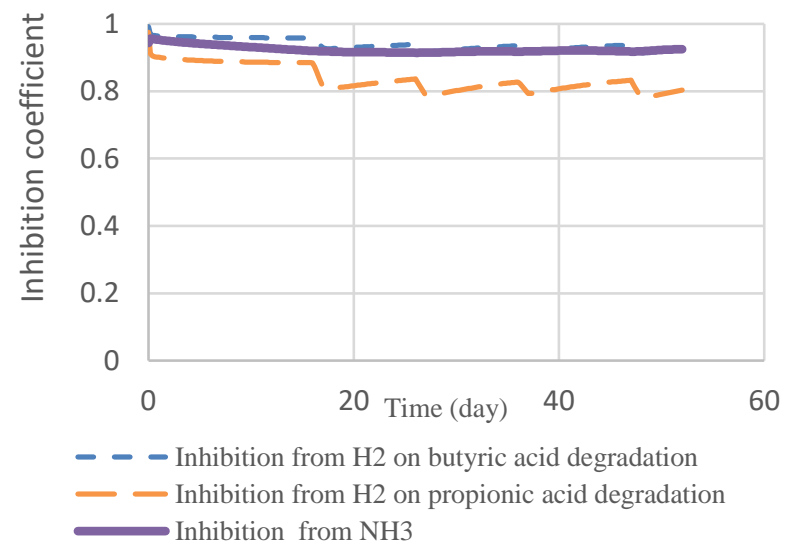

Figure 7. Simulated inhibitors coefficients (value 1 implies no inhibition and 0 implies complete inhibition).

Inorganic nitrogen may also cause AD inhibition both if in excess or in shortage, the latter typical for such feeds, compensated by ammonium supplement (Table
1). Measured and simulated ammonia levels and the inhibition simulations (Figure 7) show appropriate ammonia levels implying the amount of inorganic nitrogen added to this lignocellulosic substrate was appropriate.

Despite previous reports about the sensitivity of thermophilic AD and its poor stability, the efficient UASB reactor treatment of lignocellulosic hydrolysate suggests it is a good option for such feeds. The quite good predictability by the standard ADM1 with previously recommended process parameters support this claim and implies that ADM1 can be used in process design and to test process limitations.

\section{Conclusion}

- The study shows that the thermophilic AD of lignocellulosic hydrolysate in a UASB can be simulated well by the ADM1 model.

- The hydrolysis kinetic rate constant of


thermophilic degradation of hydrolysate of Norwegian spruce.

- The low concentrations of effluent VFAs and CODs, simulated and measured, implies good digestion for the organic loading rates between 0.65 and $3.88 g$ COD $L^{-1} d^{-1}$ tested and implies that the last $\mathrm{AD}$ steps were not limiting the overall process performance.

- Hydrolysis appeared to be the overall rate limiting step in AD of such feed in UASB.

- The microbial granular sludge from mesophilic paper-mill effluent treatment adapted both to change from the mesophilic $\left(35^{\circ} \mathrm{C}\right)$ to thermophilic $\left(55^{\circ} \mathrm{C}\right)$ and to increased load.

- The largest simulated inhibition was from $\mathrm{H}_{2}$ reducing the propionate degradation but there may have been some un-accounted for inhibitor(s) causing slightly less methane production than simulated at the higher loads.

- Thermophilic AD in UASB appears to be a good treatment option for lignocellulosic hydrolysate.

- The standard ADM1 can be used in process design for thermophilic UASB AD of lignocellulosic hydrolysate.

\section{Acknowledgements}

The project was supported by Pyrogas Project funded by The Norwegian Research Council and the University of South-Eastern Norway. The authors wish to thank Jitendra Sah and Vibeke Bredvold Karlsen for the good cooperation in carrying out the experiments and modeling. 


\section{References}

T.E. Amidon and S. Liu. Water-based woody biorefinery. Biotechnology advances, 27:542-550, 2009. https://doi.org/10.1016/j.biotechadv.2009.04.012.

B.E.L Baeta, H. Luna, A.L. Sanson, S.d.Q. Silva, and S.F.D. Aquino. Degradation of a model azo dye in submerged anaerobic membrane bioreactor (SAMBR) operated with powdered activated carbon (PAC). Journal of environmental management, 128:462-470, 2013. https://doi.org/10.1016/j.jenvman.2013.05.038.

D.J. Batstone, J. Keller, J. Angelidaki, S.V. Kalyuzhnyi, S.G. Pavlostathis, A. Rozzi, W.T.M. Sanders, H. Siegrist, and V.A. Vavilin. The IWA anaerobic digestion model no 1 (ADM1). Water Science and Technology, 45: 65-73, 2002. https://doi.org/10.2166/wst.2002.0292.

D.J. Batstone, J. Keller, J. Angelidaki, S.V. Kalyuzhnyi, S.G. Pavlostathis, A. Rozzi, W.T.M. Sanders, H. Siegrist, and V.A. Vavilin. Anaerobic digestion model No. 1 (ADM1). IWA Publishing: London, UK. 2002.

W.H. Bergland, C. Dinamarca, M. Toradzadegan, A.S.R. Nordgård, I. Bakke, and R. Bakke. High Rate Manure Supernatant Digestion. Water Research, 76:1-9, 2015. http://dx.doi.org/10.1016/j.watres.2015.02.051.

A. David, T. Govil, A. Tripathi, J. McGeary, K. Farrar, and R. Sani. Thermophilic Anaerobic Digestion: Enhanced and Sustainable Methane Production from Co-Digestion of Food and Lignocellulosic Wastes. Energies, 11(8): 2058, 2018. https://doi.org/10.3390/en11082058.

M.A. Eddy, F.L. Burton, G. Tchobanoglous, and R. Tsuchihashi. Wastewater engineering: treatment and Resource recovery. McGraw-Hill Education: New York, NY, USA. 2013.

G. Gebreeyessus and P. Jenicek. Thermophilic versus mesophilic anaerobic digestion of sewage sludge: a comparative review. Bioengineering, 3(2): 15, 2016. https://doi.org/10.3390/bioengineering3020015.

T. Gehring, M. Lübken, K. Koch, and M. Wichern. ADM1 simulation of the thermophilic mono-fermentation of maize silage-Use of an uncertainty analysis for substrate characterization. In 13th World Congress on Anaerobic Digestion: Recovering (bio) Resources for the World, 28, 2013.

M. Kamali, T. Gameiro, M.E.V. Costa, and I. Capela. Anaerobic digestion of pulp and paper mill wastes-An overview of the developments and improvement opportunities. Chemical Engineering Journal, 298: 162182, 2016. https://doi.org/10.1016/j.cej.2016.03.119.

P. Kaparaju, M. Serrano, and I. Angelidaki. Effect of reactor configuration on biogas production from wheat straw hydrolysate. Bioresource technology, 100: 6317-6323, 2009. https://doi.org/10.1016/j.biortech.2009.06.101.

T. Karuppiah and V.E. Azariah. Biomass Pretreatment for Enhancement of Biogas Production. IntechOpen. 2019. https://doi.org/10.5772/intechopen.82088.

M. Kim, Y.H. Ahn, and R. Speece. Comparative process stability and efficiency of anaerobic digestion; mesophilic vs. thermophilic. Water research, 36: 4369-4385, 2002. https://doi.org/10.1016/S0043-1354(02)00147-1.
A.S.R. Nordgård, W.H. Bergland, O. Vadstein, V. Mironov, R. Bakke, K. Østgaard, and I. Bakke. Anaerobic digestion of pig manure supernatant at high ammonia concentrations characterized by high abundance of Mathanosaeta and noneuryarchaeotal archaea. Scientific Reports, 7(1): 15077, 2017. http://dx.doi.org/10.1038/s41598-017-14527-1.

R. J. Patinvoh, O.A. Osadolor, K. Chandolias, I.S. Horváth, and M.J. Taherzadeh. Innovative pretreatment strategies for biogas production. Bioresource technology, 224: 13-24, 2017. https://doi.org/10.1016/j.biortech.2016.11.083.

M. Taherzadeh and K. Karimi. Pretreatment of lignocellulosic wastes to improve ethanol and biogas production: a review. International journal of molecular sciences, 9:1621-1651, 2008. https://doi.org/10.3390/ijms9091621.

O. Therasme, T.A. Volk, A.M. Cabrera, M.H. Eisenbies, and T.E. Amidon. Hot Water Extraction Improves the Characteristics of Willow and Sugar Maple Biomass with Different Amount of Bark. Frontiers in Energy Research, 6: 93, 2018. https://doi.org/10.3389/fenrg.2018.00093.

Y. Xia, H.H. Fang and T. Zhang. Recent studies on thermophilic anaerobic bioconversion of lignocellulosic biomass. RSC Advances, 3(36): 15528-15542, 2013.

K. Østgaard, V. Kowarz, W. Shuai, I.A. Henry, M. Sposob, H.H. Haugen, and R. Bakke. Syringe test screening of microbial gas production activity: Cases denitrification and biogas formation. Journal of Microbiological Methods,132:119-124, 2017. https://doi.org/10.1016/ j.mimet.2016.11.021. 